\title{
State Ownership, Auditor Rotation and Audit Quality
}

\author{
Liangcheng Wang \\ Business School \\ Sichuan University \\ Chengdu, China 610064
}

\author{
Lin Zhu \\ Business School \\ Sichuan University \\ Chengdu, China 610064
}

\begin{abstract}
This paper examines whether the auditor rotation affects the audit quality of state owned enterprises (SOEs) based on the data of China's listed companies that switching audit firms in the period from 2004 to 2014. The results from our sample show that the auditor rotation has significant positive impact on the audit quality of central SOEs, but not local SOEs or non-state-owned enterprises. Further analysis divides the auditor rotation into the compulsory and the optional according to the SASAC rules. The result shows that the compulsory rotation behaves better than optional rotation in improving the auditing quality for central SOEs. This paper provides some empirical evidences for perfecting the SASAC rules and China's auditing markets.
\end{abstract}

\section{Keywords-state ownership; auditor rotation; audit quality}

\section{INTRODUCTION}

Since 2003, the productivity of state owned enterprises (SOEs) has been developing slowly. Traditional industries including steel, coal, petroleum and petrochemical suffered from continuous losses and serious overcapacity. To deal with that problem, Chinese government began to strengthen structural reform of the supply front to increase the quality and efficiency of supply system and provide a growth impetus for sustainable economic development. On the other hand, as the major investor of SOEs, SASAC has adopted a series of rules to strengthen the management and control the audit quality of SOEs, including "Central Enterprises Financial Auditing Rules"(SASAC 2004[173], SASAC 2005[43]) and "Central Enterprises Financial Report Management Measures"(SASAC No.5). These documents made many restrictions in hiring and firing auditing firms, which directly caused the compulsory auditor rotation in SOEs.

To examine whether the auditor rotation affects the audit quality of SOEs, this paper investigates China's listed enterprises that switched audit firms in the period between 2004 and 2014, and uses discretionary accruals as the proxy for audit quality. The results from our sample show that the auditor rotation has significant positive impact on audit quality of central SOEs, but not local SOEs or non-stateowned enterprises. Further analysis divides the auditor rotation into compulsory and optional according to SASAC rules to research the difference of effect between the compulsory auditor rotation and the optional one. The result shows that the compulsory rotation behaves better than optional rotation in improving the auditing quality for central SOEs which indicates that the SASAC rules took effect.
The remainder of the paper proceeds as follows. Section 2 develops the theoretical analysis and the research hypotheses. Section 3 describes the research design. Section 4 presents the results of regression analysis. Finally, Section 5 concludes the study.

\section{THEORETICAL ANALYSIS AND THE RESEARCH HYPOTHESIS}

Auditor finds and reports the major misstatements in clients' financial statements according to the enterprise accounting standards and accounting professional judgement There are many arguments about the relationship between the audit quality and the auditor rotation or auditing tenure. Vanstraelen (2000) found that auditing opinions were cleaner in the first two years of the auditing term compared to the last year, and long tenure of auditing significantly reduced the probability of non-standard auditing opinions. Dopuch, King and Schwartz (2001) found that the implementation of regular audit rotation system significantly improved audit independence. Kim, Min and Yi (2004) found that the discretionary accruals of the Korean listed companies under the semi-compulsory rotation were lower, so the auditor rotation system had a substantial impact on financial reporting. Daniels and Booker (2006) found that the enforcement of compulsory rotation changed the perception of the auditing independence but not the audit quality. Geiger and Raghunandan (2002), Ghosh and Moon (2005) think that limited audit tenure is not conducive to the accumulation of audit experience and the improvement of auditing professional competency. Zhang et al.(2011) found that the system of compulsory rotation has not significantly improved the quality of audit. So, this chapter puts forward the following hypothesis:

Hypothesis 1 The audit quality is positively associated with the auditor rotation.

According to the series of rules that SASAC has made in China, there are three situations that the company's audit firm has to be switched: (1)The tenure of audit firm is about to expire the limitation of SASAC rules (five years usually); (2)The original audit firm can't continue to meet the requirements of SASAC such as the professional qualification and the number of CPA; (3)The company is listed in the annual financial random inspection. Under the guidance and restriction from SASAC, the impact of compulsory auditor rotation has attracted the attention of academia. Wang et al. (2010) investigated SOEs that 
switched audit firms as SASAC regulated and found that the audit quality under the new audit firms ISN'T significantly higher than the audit quality of these same companies one year earlier under the old audit firms, which is consistent with the results of DeFond et al. (2000). Hu et al. (2015) found that financial restatements of listed SOEs were significantly lower under auditors selected by SASAC through open tender, which indicates that the audit quality was positively associated with auditor selection made by SASAC. Based on the SASAC rules that would cause the compulsory auditor rotation in SOEs, this chapter puts forward the following hypothesis:

Hypothesis 2 The increment of audit quality of SOEs is positively associated with the compulsory auditor rotation by SASAC.

\section{RESEARCH DESIGN}

\section{A. Regression Model}

Audit quality is the joint probability for auditor to find and report the major misstatements in companies' financial statements (DeAngelo, 1981). As a result, the leverage of earnings management which is usually represented by discretionary accruals in companies' financial statements which have been audited are often used to represent the audit quality. This paper uses discretionary accruals as proxy for earnings management leverage to study the correlation between audit quality and auditor rotation, and build the following Eq.(1) to carry out the empirical test:

$$
\mathrm{Da}=\beta_{0}+\beta_{1} A \mathrm{r}+\Sigma \beta_{i} \text { Control }+\varepsilon
$$

In Eq. (1), the dependent variable is the discretionary accruals (Da) which is estimated by the cross section regression in each year and industry according to the Modified Jones Model (Dechow et al., 1995) as followed.

$$
\frac{T A_{t}}{A_{t-1}}=\alpha_{0}\left(\frac{1}{A_{t-1}}\right)+\alpha_{1}\left(\frac{\Delta R E V_{t}}{A_{t-1}}\right)+\alpha_{2}\left(\frac{P P E_{t}}{A_{t-1}}\right)+\varepsilon_{t}
$$

(a)

(b)

$$
N D A_{t}=\alpha_{0}\left(\frac{1}{A_{t-1}}\right)+\alpha_{1}\left(\frac{\Delta R E V_{t}-\Delta R E C_{t}}{A_{t-1}}\right)+\alpha_{2}\left(\frac{P P E_{t}}{A_{t-1}}\right)
$$

$$
D \mathrm{~A}_{t}=\frac{T \mathrm{~A}_{t}}{\mathrm{~A}_{t-1}}-N D \mathrm{~A}_{t}
$$

Variables in the Modified Jones Model: TAt (total accruals)-the value of operating profit minus operating cash flow of the company in year t; At-1-the value of assets of the company in year $\mathrm{t}-1 ; \triangle \mathrm{REVt}$-the increment of revenue in year $\mathrm{t}$; PPEt-the original value of fixed assets in year $\mathrm{t}$; NDAt (non-discretionary accruals) - the value which is calculated by Eq. (b) using the parameters from the regression of Eq. (a) in year $\mathrm{t} ; \triangle \mathrm{RECt}$-the increment of accounts receivable in year $t$; DAt(discretionary accruals)the value of TAt divided by At-1 minus NDAt.
In Eq. (1), the independent variable is $\operatorname{Ar}$ (Audit Rotation) -dummy variable, 1 if the company rotates its audit firm during the year, 0 otherwise. Control variables: Size-the natural logarithm of the total assets of the company. Growththe company's growth rate of operating income. Roa (return on assets)-The net profit divided by total assets; Lev (financial leverage)-Total debts divided by total equity; Tat (total asset turnover)-The sales divided by total assets; Cr(current ratio)-current assets divided by current total debts. Loss-dummy variable, 1 if the company's net profit is negative, 0 otherwise. Big4-dummy variable, 1 if the company is audited by the international big four, 0 otherwise.Fee-the natural logarithm of the domestic auditing costs of the company. In order to control the effect of extreme values of continuous variables, all continuous variables are winsorized at the top and bottom $1 \%$.

$\triangle \mathrm{Da}=\beta_{0}+\beta_{1}$ Compulsory $+\Sigma \beta_{i}$ Control $+\varepsilon$

In Eq. (2), the dependent variable is the decrements of discretionary accruals $(\triangle \mathrm{Da})$ which represents the difference of discretionary accruals between the year of auditor rotation and before. The independent variable is Compulsory-dummy variable, 1 if the auditor rotation is compulsory according to SASAC rules, 0 if the auditor rotation is optional decision made by the company itself. Control variables in Eq. (2) are the same to the control variables in Eq. (1). Besides, in order to control the effect of extreme values of continuous variables, all continuous variables in Eq. (1) and Eq. (2) are winsorized at the top and bottom $1 \%$.

\section{B. Sample Selection}

This paper selects all the listed companies in China stock markets which switched audit firms from 2004 to 2014 as research samples. We have sifted samples according to the following program:

(1)Exclude the financial listed companies because of their own characteristics;

(2)Exclude the companies whose data is missed.

After the above screening, there are 1477 samples including 461 central SOEs, 417 local SOEs and 599 nonstate-owned enterprises. The samples are distributed by years and industries as "Table I" and "Table II" shows. 
TABLE I. SAMPLE BY YEAR AND OWNERSHIP TYPE

\begin{tabular}{|l|ll|ll|ll|ll|}
\hline \multicolumn{1}{|c|}{ Year } & \multicolumn{3}{c|}{ Central SOEs } & \multicolumn{2}{c|}{ Local SOEs } & \multicolumn{2}{c|}{ Non-state-owned } & \multicolumn{2}{c|}{ Total } \\
\hline 2004 & 17 & $(3.69 \%)$ & 35 & $(8.39 \%)$ & 50 & $(8.35 \%)$ & 102 & $(6.91 \%)$ \\
\hline 2005 & 45 & $(9.76 \%)$ & 41 & $(9.83 \%)$ & 50 & $(8.35 \%)$ & 136 & $(9.21 \%)$ \\
\hline 2006 & 67 & $(14.53 \%)$ & 35 & $(8.39 \%)$ & 49 & $(8.18 \%)$ & 151 & $(10.22 \%)$ \\
\hline 2007 & 42 & $(9.11 \%)$ & 46 & $(11.03 \%)$ & 56 & $(9.35 \%)$ & 144 & $(9.75 \%)$ \\
\hline 2008 & 56 & $(12.15 \%)$ & 32 & $(7.67 \%)$ & 39 & $(6.51 \%)$ & 127 & $(8.60 \%)$ \\
\hline 2009 & 37 & $(8.03 \%)$ & 39 & $(9.35 \%)$ & 39 & $(6.51 \%)$ & 115 & $(7.79 \%)$ \\
\hline 2010 & 25 & $(5.42 \%)$ & 38 & $(9.11 \%)$ & 39 & $(6.51 \%)$ & 102 & $(6.91 \%)$ \\
\hline 2011 & 44 & $(9.54 \%)$ & 37 & $(8.87 \%)$ & 82 & $(13.69 \%)$ & 163 & $(11.04 \%)$ \\
\hline 2012 & 50 & $(10.85 \%)$ & 39 & $(9.35 \%)$ & 69 & $(11.52 \%)$ & 158 & $(10.70 \%)$ \\
\hline 2013 & 44 & $(9.54 \%)$ & 31 & $(7.43 \%)$ & 60 & $(10.02 \%)$ & 135 & $(9.14 \%)$ \\
\hline 2014 & 34 & $(7.38 \%)$ & 44 & $(10.55 \%)$ & 66 & $(11.02 \%)$ & 144 & $(9.75 \%)$ \\
\hline Total & 461 & $(100.00 \%)$ & 417 & $(100.00 \%)$ & 599 & $(100.00 \%)$ & 1477 & $(100.00 \%)$ \\
\hline
\end{tabular}

TABLE II. SAMPLE BY INDUSTRY AND OWNERSHIP TYPE

\begin{tabular}{|l|ll|ll|ll|ll|}
\hline Industry & \multicolumn{2}{|c|}{ Central SOEs } & \multicolumn{2}{|c|}{ Local SOEs } & \multicolumn{2}{|c|}{ Non-state-owned } & \multicolumn{2}{c|}{ Total } \\
\hline $\mathrm{A}$ & 5 & $(1.08 \%)$ & 5 & $(1.20 \%)$ & 9 & $(1.50 \%)$ & 19 & $(1.29 \%)$ \\
\hline B & 18 & $(3.90 \%)$ & 22 & $(5.28 \%)$ & 18 & $(3.01 \%)$ & 58 & $(3.93 \%)$ \\
\hline C0 & 3 & $(0.65 \%)$ & 23 & $(5.52 \%)$ & 33 & $(5.51 \%)$ & 59 & $(3.99 \%)$ \\
\hline C1 & 6 & $(1.30 \%)$ & 5 & $(1.20 \%)$ & 30 & $(5.01 \%)$ & 41 & $(2.78 \%)$ \\
\hline C2 & 0 & $(0.00 \%)$ & 0 & $(0.00 \%)$ & 6 & $(1.00 \%)$ & 6 & $(0.41 \%)$ \\
\hline C3 & 3 & $(0.65 \%)$ & 10 & $(2.40 \%)$ & 15 & $(2.50 \%)$ & 28 & $(1.90 \%)$ \\
\hline C4 & 48 & $(10.41 \%)$ & 51 & $(12.23 \%)$ & 47 & $(7.85 \%)$ & 146 & $(9.88 \%)$ \\
\hline C5 & 24 & $(5.21 \%)$ & 12 & $(2.88 \%)$ & 27 & $(4.51 \%)$ & 63 & $(4.27 \%)$ \\
\hline C6 & 55 & $(11.93 \%)$ & 46 & $(11.03 \%)$ & 32 & $(5.34 \%)$ & 133 & $(9.00 \%)$ \\
\hline C7 & 104 & $(22.56 \%)$ & 57 & $(13.67 \%)$ & 80 & $(13.36 \%)$ & 241 & $(16.32 \%)$ \\
\hline C8 & 20 & $(4.34 \%)$ & 18 & $(4.32 \%)$ & 52 & $(8.68 \%)$ & 90 & $(6.09 \%)$ \\
\hline C9 & 0 & $(0.00 \%)$ & 4 & $(0.96 \%)$ & 6 & $(1.00 \%)$ & 10 & $(0.68 \%)$ \\
\hline D & 31 & $(6.72 \%)$ & 31 & $(7.43 \%)$ & 7 & $(1.17 \%)$ & 69 & $(4.67 \%)$ \\
\hline E & 15 & $(3.25 \%)$ & 8 & $(1.92 \%)$ & 11 & $(1.84 \%)$ & 34 & $(2.30 \%)$ \\
\hline F & 20 & $(4.34 \%)$ & 23 & $(5.52 \%)$ & 17 & $(2.84 \%)$ & 60 & $(4.06 \%)$ \\
\hline G & 55 & $(11.93 \%)$ & 8 & $(1.92 \%)$ & 60 & $(10.02 \%)$ & 123 & $(8.33 \%)$ \\
\hline H & 17 & $(3.69 \%)$ & 14 & $(3.36 \%)$ & 23 & $(3.84 \%)$ & 54 & $(3.66 \%)$ \\
\hline J & 20 & $(4.34 \%)$ & 43 & $(10.31 \%)$ & 63 & $(10.52 \%)$ & 126 & $(8.53 \%)$ \\
\hline K & 11 & $(2.39 \%)$ & 14 & $(3.36 \%)$ & 27 & $(4.51 \%)$ & 52 & $(3.52 \%)$ \\
\hline L & 3 & $(0.65 \%)$ & 9 & $(2.16 \%)$ & 9 & $(1.50 \%)$ & 21 & $(1.42 \%)$ \\
\hline M & 3 & $(0.65 \%)$ & 14 & $(3.36 \%)$ & 27 & $(4.51 \%)$ & 44 & $(2.98 \%)$ \\
\hline Total & 461 & $(100.00 \%)$ & 417 & $(100.00 \%)$ & 599 & $(100.00 \%)$ & 1477 & $(100.00 \%)$ \\
\hline
\end{tabular}

\section{THE EMPIRICAL TeSt AND ANALYsis}

\section{A. Descriptive Statistical Analysis}

To compare the audit quality before and after the auditor rotation, this chapter examines whether the audit quality under the new audit firms is higher than that under the old audit firms in the past two years. "Table III" is the descriptive statistics of the main variables.

As the results show, in general, the leverage of discretionary accruals $(\mathrm{Da})$ under the new audit firms is lower than that under the old audit firms in the past two years, suggesting that the auditor rotation improved the audit quality to some degrees, along with the higher Size and Growth. For central SOEs, the mean value of Da after the auditor rotation is -0.0025 which is significantly lower than that before the auditor rotation (0.0154). The auditor rotation also brought the higher leverages of Lev, Tat, and Loss and the lower of Roa and Cr. For local SOEs, the leverage of Da was also lower but not significantly after the auditor rotation by comparing the mean values of -0.0024 and 0.0086 . And mean the values of Roa and Tat were increased, and the the values of Lev, $\mathrm{Cr}$ and Loss are decreased. For non-stateowned enterprises, the mean value of Da after the auditor rotation is -0.0004 which is also lower than the value before $(0.0069)$. And the mean values of Roa, Lev and $\mathrm{Cr}$ were higher and the probability of Loss was lower. Besides, the results show that the audit cost (Fee) is significantly higher after the auditor rotation and there was less probability of hiring the international big four (Big4) for both SOEs and non-state-owned enterprises. The results of descriptive statistics indicates that although the operating and financial risks changed in different ways to companies of different ownership types, the the leverages of discretionary accruals after the auditor rotation were lower, that is to say the auditor rotation improved the audit quality. 
TABLE III. DESCRIPTIVE STATISTICS

\begin{tabular}{|c|c|c|c|c|c|c|c|c|c|c|c|c|}
\hline & \multicolumn{3}{|c|}{ Central SOES } & \multicolumn{3}{|c|}{ Local SOES } & \multicolumn{3}{|c|}{ Non-state-owned } & \multicolumn{3}{|c|}{ Total } \\
\hline & \begin{tabular}{|l} 
(1) \\
Mean
\end{tabular} & $\begin{array}{l}\text { (2) } \\
\text { Mean }\end{array}$ & $\mathrm{t}$ & $\begin{array}{l}(1) \\
\text { Mean }\end{array}$ & $\begin{array}{l}(2) \\
\text { Mean }\end{array}$ & $\mathrm{t}$ & $\begin{array}{l}\text { (1) } \\
\text { Mean }\end{array}$ & $\begin{array}{l}(2) \\
\text { Mean }\end{array}$ & $\mathrm{t}$ & \begin{tabular}{|l}
1 ) \\
Mean
\end{tabular} & $\begin{array}{l}2) \\
\text { Mean }\end{array}$ & $t$ \\
\hline $\mathrm{Da}$ & -0.0025 & 0.0154 & $-2.5456 * * *$ & -0.0024 & 0.0086 & -1.0323 & 0.0026 & -0.0016 & 0.3875 & -0.0004 & 0.0069 & -1.2713 \\
\hline Size & 22.0968 & 21.9275 & $2.0366 * *$ & 21.9415 & 21.6628 & $3.332 * * *$ & 20.9499 & 20.7883 & $2.6895 * * *$ & 21.5876 & 21.4169 & $3.7029 * * *$ \\
\hline Growth & 1.3245 & 1.3005 & 0.3837 & 1.6221 & 1.2356 & $4.1035^{* * *} *$ & 1.6744 & 1.3021 & $3.6261 * * *$ & 1.5499 & 1.2813 & $5.1037 * * *$ \\
\hline Roa & 0.0328 & 0.0405 & $-1.8197 * *$ & 0.0236 & 0.0213 & 0.3664 & 0.0076 & 0.0048 & 0.3378 & 0.0200 & 0.0212 & -0.2886 \\
\hline Lev & 0.5437 & 0.5226 & 1.2571 & 0.5961 & 0.6051 & -0.4373 & 0.6072 & 0.5867 & 0.7167 & 0.5842 & 0.5719 & 0.894 \\
\hline Tat & 0.77405 & 0.7396 & 1.208 & 0.6495 & 0.6386 & 0.3891 & 0.5351 & 0.5406 & -0.2359 & 0.6426 & 0.6339 & 0.5615 \\
\hline $\mathrm{Cr}$ & 1.6551 & 1.7555 & -1 & 1.2970 & 1.3270 & -0.4042 & 2.2318 & 2.0036 & $1.7638 * *$ & 1.785 & 1.7196 & 1.0099 \\
\hline Loss & 0.15618 & 0.1350 & 1.0257 & 0.1703 & 0.1986 & -1.1817 & 0.1987 & 0.2748 & $-3.3758 * * *$ & 0.1774 & 0.2072 & $-2.2701 * *$ \\
\hline Big4 & 0.1128 & 0.1337 & -1.0671 & 0.0983 & 0.1233 & -1.2785 & 0.0317 & 0.0596 & $-2.468 * * *$ & 0.0758 & 0.1025 & $-2.7916^{* * *}$ \\
\hline Fee & 13.2705 & 13.2048 & $1.5818^{*}$ & 13.2983 & 13.2045 & $2.2154 * *$ & 13.1070 & 13.0255 & 2.7663 **** & 13.2113 & 13.1366 & $3.4623 * * *$ \\
\hline $\mathrm{N}$ & 461 & 763 & & 417 & 730 & & 599 & 906 & & 1,477 & 2,399 & \\
\hline
\end{tabular}

\section{B. Regression Analysis}

"Table IV" shows the regression result of model (1). According to the regression result, there is a significant negative relationship between Da and Ar for central SOEs, indicating that the audit quality is higher after the audit rotation, supporting hypothesis 1 . However, for local SOEs b. $* * *, * *$, and * represent statistical significance at the $1 \%, 5 \%$, and $10 \%$ levels. and non-state-owned companies, the negative relationships between $\mathrm{Da}$ and Ar are not significant. As for the control variables, Roa is significantly positive with $\mathrm{Da}$ when Tat is significantly negative with $\mathrm{Da}$, suggesting that the companies with higher Roa or lower Tat tend to create higher discretionary accruals.

TABLE IV. The Regression Result of Model (1)

\begin{tabular}{|c|c|c|c|c|}
\hline & Central SOEs & Local SOES & Non-state-owned & Total \\
\hline $\mathrm{Ar}$ & $\begin{array}{l}-0.0152104 \\
(-1.91 *)\end{array}$ & $\begin{array}{l}-0.0163418 \\
(-1.49)\end{array}$ & $\begin{array}{l}-0.0111733 \\
(-1.06)\end{array}$ & $\begin{array}{l}-0.013893 \\
(-2.42 * *)\end{array}$ \\
\hline Size & $\begin{array}{l}-0.0101219 \\
(-2.07 * *)\end{array}$ & $\begin{array}{l}0.0001597 \\
(0.03)\end{array}$ & $\begin{array}{l}-0.0012549 \\
(-0.22)\end{array}$ & $\begin{array}{l}-0.004434 \\
(-1.51)\end{array}$ \\
\hline Growth & $\begin{array}{l}0.0062093 \\
\left(1.86^{*}\right)\end{array}$ & $\begin{array}{l}-0.0066987 \\
(-1.97 * *)\end{array}$ & $\begin{array}{l}-0.0088306 \\
(-3.61 * * *)\end{array}$ & $\begin{array}{l}-0.0058412 \\
(-3.56 * * *)\end{array}$ \\
\hline Roa & $\begin{array}{l}0.4646896 \\
(6.57 * * *)\end{array}$ & $\begin{array}{l}0.5974258 \\
(9.32 * * *)\end{array}$ & $\begin{array}{l}0.7567641 \\
(17.75 * * *)\end{array}$ & $\begin{array}{l}0.6933632 \\
(23.59 * * *)\end{array}$ \\
\hline Lev & $\begin{array}{l}-0.0185392 \\
(-1.14)\end{array}$ & $\begin{array}{l}0.0277378 \\
(1.38)\end{array}$ & $\begin{array}{l}0.0134259 \\
(1.12)\end{array}$ & $\begin{array}{l}0.0135804 \\
\left(1.66^{*}\right)\end{array}$ \\
\hline Tat & $\begin{array}{l}-0.0137327 \\
(-1.62)\end{array}$ & $\begin{array}{l}-0.0286103 \\
(-2.32 * *)\end{array}$ & $\begin{array}{l}-0.0289318 \\
\left(-2.5^{* *}\right)\end{array}$ & $\begin{array}{l}-0.0254345 \\
(-4.17 * * *)\end{array}$ \\
\hline $\mathrm{Cr}$ & $\begin{array}{l}0.0021026 \\
(0.79)\end{array}$ & $\begin{array}{l}0.002029 \\
(0.45)\end{array}$ & $\begin{array}{l}-0.0024203 \\
(-1.05)\end{array}$ & $\begin{array}{l}-0.0003805 \\
(-0.24)\end{array}$ \\
\hline Loss & $\begin{array}{l}0.0033454 \\
(0.25)\end{array}$ & $\begin{array}{l}-0.0154777 \\
(-0.92)\end{array}$ & $\begin{array}{l}0.0043349 \\
(0.29)\end{array}$ & $\begin{array}{l}0.0007781 \\
(0.09)\end{array}$ \\
\hline Big4 & $\begin{array}{l}0.0098838 \\
(0.71)\end{array}$ & $\begin{array}{l}-0.0079764 \\
(-0.41)\end{array}$ & $\begin{array}{l}-0.0751066 \\
(-2.92 * * *)\end{array}$ & $\begin{array}{l}-0.0168127 \\
(-1.53)\end{array}$ \\
\hline Fee & $\begin{array}{l}0.011312 \\
(1.21)\end{array}$ & $\begin{array}{l}0.0048899 \\
(0.39)\end{array}$ & $\begin{array}{l}0.0219 \\
\left(0.68^{*}\right)\end{array}$ & $\begin{array}{l}0.0107495 \\
(1.62)\end{array}$ \\
\hline Year & yes & yes & yes & yes \\
\hline Industry & yes & yes & yes & yes \\
\hline $\mathrm{N}$ & 1,066 & 984 & 1,309 & 3,359 \\
\hline $\operatorname{Adj~} \mathrm{R}^{2}$ & 0.0992 & 0.1475 & 0.3098 & 0.2233 \\
\hline $\mathrm{F}$ & $3.93 * * *$ & $5.15 * * *$ & $14.98 * * *$ & 23.99 \\
\hline
\end{tabular}

"Table V" shows the regression result of model (2) and indicates the difference of effect between the compulsory auditor rotation and the optional one. According to the regression result, there is a significant positive relationship between $\triangle \mathrm{Da}$ and Compulsory for central SOEs, suggesting that the compulsory auditor rotation behaves betters in 
improving the audit quality than optional rotation, consistent with hypothesis 2 . However for local SOEs, the positive relationship between $\triangle \mathrm{Da}$ and Compulsory are not significant, suggesting that there is no significant difference between compulsory and optional auditor rotation in local SOEs. As for the control variables, Roa and Fee are significantly negative with $\triangle \mathrm{Da}$, suggesting that the improvement of audit quality may be weakened by companies' good behavior in profitability or paying a higher fee to audit firms.

TABLE V. The REgReSSION RESUlt OF Model (2)

\begin{tabular}{|c|c|c|c|}
\hline & Central SOEs & Local SOEs & Total \\
\hline Compulsory & $\begin{array}{l}0.0390988 \\
(2.12 * *)\end{array}$ & $\begin{array}{l}0.0108019 \\
(0.25)\end{array}$ & $\begin{array}{l}0.0273817 \\
(1.59)\end{array}$ \\
\hline Size & $\begin{array}{l}0.0177096 \\
(1.53)\end{array}$ & \begin{tabular}{|l|}
0.0293633 \\
$(1.95 *)$
\end{tabular} & $\begin{array}{l}0.0201226 \\
(2.23 * *)\end{array}$ \\
\hline Growth & $\begin{array}{l}0.0023744 \\
(0.35)\end{array}$ & $\begin{array}{l}0.0014918 \\
(0.23)\end{array}$ & $\begin{array}{l}0.0045481 \\
(1.03)\end{array}$ \\
\hline Roa & $\begin{array}{l}-0.4385304 \\
(-2.96 * * *)\end{array}$ & $\begin{array}{l}-0.559328 \\
(-3.21 * * *)\end{array}$ & $\begin{array}{l}-0.5808244 \\
(-5.25 * * *)\end{array}$ \\
\hline Lev & $\begin{array}{l}-0.0451792 \\
(-1)\end{array}$ & $\begin{array}{l}0.0009986 \\
(0.02)\end{array}$ & $\begin{array}{l}-0.0250968 \\
(-0.69)\end{array}$ \\
\hline Tat & $\begin{array}{l}-0.0257065 \\
(-1.32)\end{array}$ & $\begin{array}{l}0.0154628 \\
(0.52)\end{array}$ & $\begin{array}{l}-0.0024467 \\
(-0.15)\end{array}$ \\
\hline $\mathrm{Cr}$ & $\begin{array}{l}-0.0046924 \\
(-0.64)\end{array}$ & $\begin{array}{l}0.0080244 \\
(0.61)\end{array}$ & $\begin{array}{l}0.00000272 \\
(0)\end{array}$ \\
\hline Loss & $\begin{array}{l}-0.0066824 \\
(-0.21)\end{array}$ & $\begin{array}{l}0.097542 \\
(2.07 * *)\end{array}$ & $\begin{array}{l}0.0403147 \\
(1.48)\end{array}$ \\
\hline Big4 & $\begin{array}{l}0.0370717 \\
(1.09)\end{array}$ & $\begin{array}{l}-0.0465846 \\
(-0.86)\end{array}$ & $\begin{array}{l}0.0071611 \\
(0.24)\end{array}$ \\
\hline Fee & $\begin{array}{l}-0.0450189 \\
(-2 * *)\end{array}$ & $\begin{array}{l}-0.0314295 \\
(-1.04)\end{array}$ & $\begin{array}{l}-0.0379911 \\
(-2.1 * *)\end{array}$ \\
\hline Year & yes & yes & yes \\
\hline Industry & yes & yes & yes \\
\hline N & 390 & 344 & 734 \\
\hline Adj R ${ }^{2}$ & 0.0526 & 0.177 & 0.1248 \\
\hline $\mathrm{F}$ & $1.57 * *$ & 2.89 *** & $3.68^{* * * *}$ \\
\hline
\end{tabular}

f. (dependent variable: $\triangle \mathrm{Da}$ )

\section{CONCLUSION}

This paper examines whether the auditor rotation affects the audit quality of state owned enterprises (SOEs) based on the data of China's listed companies that switching audit firms in the period from 2004 to 2014. The results from our sample show that the auditor rotation has significant positive impact on the audit quality of central SOEs, but not local SOEs or non-state-owned enterprises. Further analysis divides the auditor rotation into the compulsory and the optional according to the SASAC rules. The result shows that the compulsory rotation behaves better than optional rotation in improving the auditing quality for central SOEs, that is to say for central SOEs, the audit quality is positively associated with the auditor rotation and the increment of audit quality of SOEs is positively associated with the compulsory auditor rotation by SASAC.

\section{REFERENCES}

[1] DeAngelo L.1981.Auditor size and audit quality.Journal of Accounting and Economics(3):183-199

[2] DeChow,P.M.,R.G.Sloan,and A.P.Sweeney.1995.Detecting earnings management.The Accounting Review (April) 70(2):193-225

[3] Dopuch N.\&R.Schwartz.2001.An experimental investigation of retention and rotation requirements.Journal of Accounting Research 39(1):93-117

[4] Daniels,B.W.,and Booker,Q..2006.The effects of audit firm rotation on perceived external auditor independence and audit quality.Auditing Section of the American Accounting Association Mid-year Meeting,Los Angeles,CA.

[5] Dao,M.,K.Raghunandan,and D.V.Rama.2012.Shareholder Voting on auditor selection, audit fees and audit quality.The Accounting Review 87(1):149 171

[6] Geiger,M.A.and K.Raghunandan.2002.Auditor tenure and audit reporting failures.Auditing:A Journal of Practice\&Theory 21(1):6778.

[7] Geisler,C.and Kin,Y.L..2008.How do various forms of audit rotation affect audit effectiveness?Nanyang Technology University Working Paper

[8] Ghosh A,Moon D.2005.Auditor tenure and perceptions of audit quality.The Accounting Review 80(2):585-612

[9] Hatfield,R.S.and Vandervelde,J.S..2006.The effects of auditor rotation and client pressure on proposed audit adjustments.University of Alabama Working Paper

[10] Hu H.,and Tang J.2015.Public biding,audit quality and audit fees.Auditing Research.(3):79-95

[11] Johnson E.,Khurana K.,Reynolds J.2002.Audit-firm tenure and the quality of financial reports.Contemporary Accounting Research 19(4):637-660

[12] Kim,J.B.,Min,C.K.,and Yi,C.H..2004.Selective auditor rotation and earnings management:Evidence from Korea[J].Hong Kong Polytechnic University Working paper

[13] Kim,J.B.,and Yi,C.H..2009.Does auditor designation by the regulatory authority improve audit quality?Evidence from Korea.Journal of Account Public Policy 28(3):207-230

[14] Lennox,C.S.,X.Wu.,and T.Zhang.2014.Does mandatory rotation of audit partners improve audit quality?The Accounting Review 89(5):1775-1803

[15] Mayhew,B.W.,and J.E.Pike.2004.Does investor selection of auditors enhance auditor independence?The Accounting Review 79(3):797882

[16] Nagy,A.L..2005.Mandatory audit firm turnover,financial reporting quality,and client bargaining power:The case of arthur andersen.Accounting Horizons (June):51-68.

[17] Vanstraelen,A..2000.Impact of renewable long-term audit mandates on audit quality.The European Accounting Review 9(3):419-442

[18] Wang,Q.,T.J.Wong,and L,Xia.2008.State ownership,the institutional environment,and auditor choice:Evidence from China.Journal of Accounting and Economics (46):112-134

[19] Wang Y.,and Sun N.2009.The research on the audit bid and audit rotation of central enterprises - based on the analysis of the questionnaire.Auditing Research (1):50-54

[20] Wang B.,Wei J.,and Su W.2010.The effect of mandatory auditor assignment on audit quality:Evidence from SASAC.Economic Management (12):111-117

[21] Zhang J.,Huang Z.,and Li M.2011.Is mandatory rotation of signing auditors improving the audit quality? - Empirical evidence from the public listed companies in China.Auditing Research (5):82-89 